\title{
円柱粗度による湾曲部河床変動の 制御に関する実験的研究 EXPERIMENTAL STUDY ON CONTROL OF BED EVOLUTION IN BENS BY USING CYLINDRICAL ROUGHNESS
}

\author{
冨永晃宏 1 ・青木健太郎 $2 \cdot$ 木村聡洋 3 \\ Akihiro TOMINAGA, Kentaro AOKI and Akihiro KIMURA \\ 1 正会員 工博 名古屋工業大学教授 工学部社会開発工学科（广466-8555 名古屋市昭和区御器所町） \\ 2 学生会員 名古屋工業大学大学院 工学研究科社会開発工学専攻（T466-8555 名古屋市昭和区御器所町） \\ 3 非会員 工修 岐阜県（广500-8507 岐阜市藪田南 2-1-1）
}

\begin{abstract}
Vegetation or pile dikes in a river may affect 3-D flow structures and can control the local scour and deposit in curved open channels. In this study, three-dimensional mean flow structures were measured in a curved open channel with various arrangements of cylindrical roughness elements. Furthermore, experiments were conducted in a movable bed and the effects of roughness on the local scour were examined. Some outer-bank arrangements of roughness can reduce the bed evolution. The secondary flow cell is generated over whole section through the roughness area and the spanwise deference of primary mean velocity becomes small in the case of submerged roughness. The streamwise variation of bed share stress indicatcs charactcristic bchaviors affected by the arrangement of the roughness area, and it gives an explanation for the tendency of bed evolution.
\end{abstract}

Key Words : cylindrical roughness, vegetation, channel bend, secondary flow, 3-D flow structures, movable bed, bed evolution

\section{1. 序論}

単湾曲部の深掘れは, 慣性力によって直流してき た流水が湾曲部で集中し, 流速が速くなり河床砂の 輸送能力が増大することと, 湾曲部で流線が曲げら れ遠心力が生じ水深が大きくなるため水路横断方向 に圧力の差が生じ，2次流が発生し掃流砂が内岸側 に移送されることによって洗据が発生する. 洪水時 の湾曲部の深掘れ深の変化は護岸等の計画に大変重 要である. 湾曲部の河床形状を支配する要因として 2 次流の重要性が指摘されており, 池田 ${ }^{1)}$, 石川・金 ${ }^{2)}$, 山坂ら ${ }^{3)}$ は 2 次流に着目した研究を行っている. しかし, 湾曲部の河道断面の複雑な境界条件に対す る流れ構造および河床変動の変化特性については, まだ多くの研究がなされているとは言い難く, 今後 の多様な川づくりに対する科学的根拠を与える上で 更なる研究が望まれる，また，湾曲部外岸側の洗掘

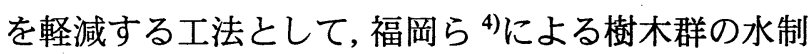
的利用の検討や Odgaard and Kennedy ${ }^{5}$ によるアイオ ワベーン工や関根・吉川 ${ }^{6}$ による外岸への栈祖度の設 置等が検討されている.これらはいずれも湾曲部特 有の 2 次流とは逆回転の 2 次流を強制的に発生させ
て，2 次流による横断方向の輸送効果を軽減しよう とするものである.

河川工学の分野においても, 近年, 樹木群に関す る研究は盛んに行われている. それらの研究により 多くのことが明らかになっているが, 樹木群の流れ 構造に関しては未知な部分が多く, 今後の研究にお いて課題になっている. また, 樹木群は一種の透過 水制のような役割を果たし, 堤防保護及び湾曲部の 河床変動の制御に利用されることも期待される.

今後河川改修を行うにあたって, 河道に繁茂する 樹木群を全て伐採し, 流路を確保するだけでは多自 然型川づくりの観点からも適当ではない. そこで本 研究では, 樹木群を円柱粗度に置き換えて, その影 響を検討するとともに, 円柱粗度に透過水制の役割 を持たせ, 湾曲部流れと河床変動を制御することに ついても検討する. 災害が集中する河道湾曲部の河 床変動に良好な影響を与える円柱粗度配置形態を考 え, 移動床および固定床実験を行い, 流速分布およ び河床形状を計測した. また, 移動床における河床 变動後の流れ構造についても検討した. その結果, 湾曲部における流れ構造, 底面せん断応力の河床に 及ぼす影響などが明らかにされた。 


\section{2. 実験方法}

実験水路は水路幅 $\mathrm{B}=90 \mathrm{~cm}$, 深さ $30 \mathrm{~cm}$, 全長 $17.2 \mathrm{~m}$ の長方形断面水路で, その平面形は図一 1 に示すよ うに上流端から $10.8 \mathrm{~m}$ の位置に湾曲角 $60^{\circ}$ の単一湾 曲部を設置し，その下流に $4.5 \mathrm{~m}$ の直線部を接続させ たものである. 湾曲部の中心曲率半径は $\mathrm{r}=2.7 \mathrm{~m}$, 曲 率半径·水路幅比 $\mathrm{r} / \mathrm{B}=3.0$, 河床勾配は $1 / 2000$ である.

円柱粗度としては, 直径 $5 \mathrm{~mm}$, 長さ $18 \mathrm{~cm}$ および $7.5 \mathrm{~cm}$ の木材の棒を使用し, 流下方向, 横断方向に $5 \mathrm{~cm}$ 間 隔で格子状に配置し，横断方向に 5 列， $22.5 \mathrm{~cm}$ にわ たって設置した. 円柱粗度は外岸側配置を基本とし て流下方向設置位置を変化させて種々のケースを設 定した. 円柱粗度の配置条件，ケース名，座標系を 表ー 1 および図－ 2 に示す．座標系は流下方向を $\mathrm{x}$ 軸, 横断方向は内岸から外岸に向かって $\mathrm{y}$ 軸, 鈶直 方向を $\mathrm{z}$ 軸とする. 外岸側下流部・湾曲角 $\theta=45^{\circ}$ か ら下流 $90 \mathrm{~cm}$ まで円柱群を設置した場合は, 円柱群全 面および側面に大きな洗掘を生じることが示されて いるため 7), これはケースから除外した. 流量は固定 床では $34 \ell / s$, 移動床では $40 \ell / s$ に設定した. 湾曲 入りロより $90 \mathrm{~cm}$ 上流において水深 $\mathrm{h}=15 \mathrm{~cm}$ となるよ うに下流の堰を調節した. 流速計には 3 成分電磁流 速計（東京計測製）を用い，湾曲入り口の $\theta=0^{\circ}$ ， 湾曲部では湾曲角 $\theta=15^{\circ}, 30^{\circ}, 45^{\circ}$, 湾曲出口の $\theta=60^{\circ}$, 湾曲下流直線部では湾曲出口から下流 $45 \mathrm{~cm}$ の 6 断面において計測を行った. また, 水深は ポイントゲージを用いて計測した.

固定床実験は河床変動の初期状態を検討する目的 で長方形断面水路の平坦床に直接円柱粗度を配置し たものである. 湾曲部の河床変動への円柱粗度配置 の影響を調べるため平均粒径 $0.05 \mathrm{~cm}$ の硅砂を湾曲上 流の $180 \mathrm{~cm}$ から湾曲下流の $200 \mathrm{~cm}$ まで厚さ $11.5 \mathrm{~cm}$ で 敷き詰めた. 対象は静的洗掘のみであり, 上流から の給砂は行っていない. 通水開始から 5 時間後の河 床形状を計測した. 流速は河床変動後の河床表面を セメントで固めた後, 3 成分電磁流速計で計測した.

円柱粗度の高さによる影響を検討する実験として は, 長さ $18 \mathrm{~cm}$ の木棒を配した非水没型実験と, 長さ $7.5 \mathrm{~cm}$ （水深の半分）の木棒を配した水没型実験の二 種類であり, 固定床および移動床状態で行った. 円 柱群が水没するものを水没型, 水没しないものを非 水没型とする. 水没型円柱のケースには添え字の $\mathrm{s}$ が付けてある. 水没型円柱の配置は非水没型円柱に 対応するように設定した. 底面せん断応力は電磁流 速計を使用したため底面近傍の流速を計測できなか ったので, 次のように求めた.

$$
\tau_{b x}=\frac{\rho C_{f}}{2} U_{b} \sqrt{U_{b}^{2}+V_{b}^{2}}
$$

ここに主流速 $U_{b}$ と横断方向流速 $V_{b}$ は底面に最も近 い点 $\mathrm{y}=1.5 \mathrm{~cm}$ での值である. $C_{f}$ は摩擦損失係数であ り, 長方形断面の湾曲上流直線部で対数則から求め た值との比較から $C_{f}=0.00065$ が得られた.
表-1 円柱群配置表

\begin{tabular}{|c|c|c|}
\hline \multicolumn{2}{|c|}{ ケース名 } & \multirow{2}{*}{ 円柱群配置位置 } \\
\hline 移動床 & 固定床 & \\
\hline $\mathrm{K}-1$ & $R-5$ & 円柱群なし \\
\hline $\mathrm{K}-4$ & $V-4$ & 上流 $90 \mathrm{~cm} \sim$ 下流 $90 \mathrm{~cm}$ \\
\hline$K-8$ & $V-8$ & 上流 $90 \mathrm{~cm} \sim$ 湾曲角 $15^{\circ}$ \\
\hline $\mathrm{K}-10$ & $V-10$ & 湾曲角 $0^{\circ} \sim$ 湾曲角 $60^{\circ}$ \\
\hline $\mathrm{Ks}-4$ & - & 上流 $90 \mathrm{~cm} \sim$ 下流 $90 \mathrm{~cm}$ \\
\hline $\mathrm{Ks}-8$ & $V s-8$ & 上流 $90 \mathrm{~cm} ＼mathrm{~ 湾 曲 角 ~} 15^{\circ}$ \\
\hline $\mathrm{Ks}-10$ & $V s-10$ & 湾曲角 $0^{\circ} \sim$ 湾曲角 $60^{\circ}$ \\
\hline
\end{tabular}
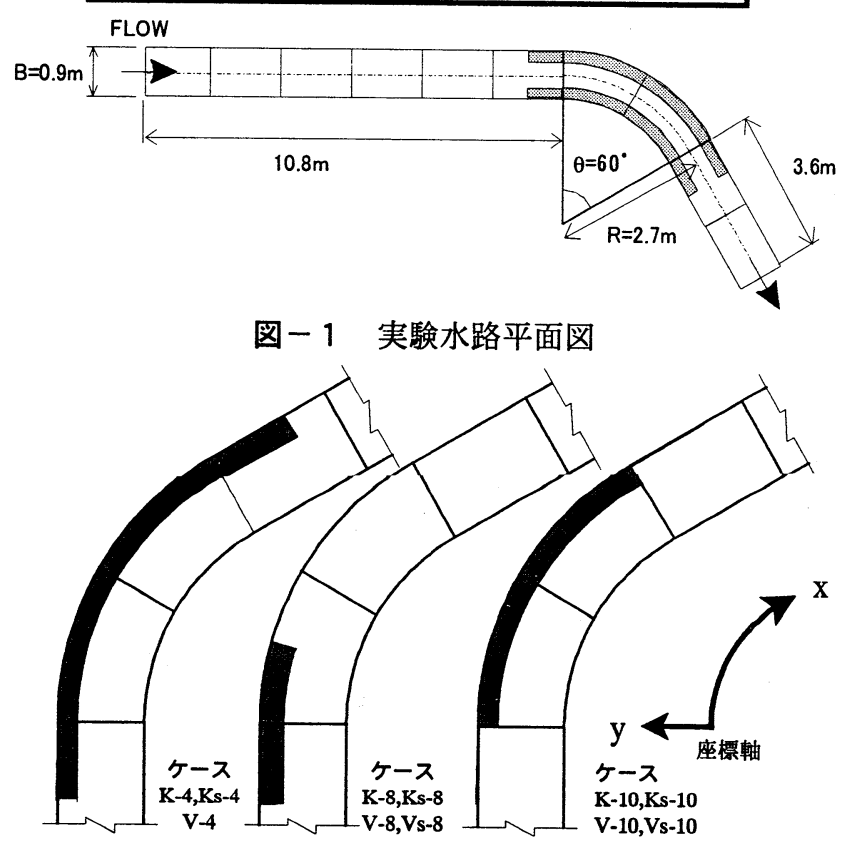

図-2 円柱群配置平面図

\section{3. 実験結果}

\section{（1）河床変動}

円柱粗度のないケース K-1 では，洗掘域は湾曲角 $\theta=35^{\circ}$ から下流 $120 \mathrm{~cm}$ の外岸側に見られた. 最大洗 掘深は湾曲出口より下流 $20 \mathrm{~cm}$ 付近で約 $10 \mathrm{~cm}$ であっ た. 堆積は湾曲角 $\theta=35^{\circ}$ から $\theta=60^{\circ}$ にかけて見ら れ, $\theta=60^{\circ}$ より下流に向かって水路中央付近へ移動 しているのが認められた 7 .

まず，図ー3，4 は各ケースの通水 5 時間後の河 床高コンター図である. 非水没型円柱を設置したケ 一スについて考察する. 外岸に円柱群を設置したケ 一ス K-4 では, 湾曲角 $\theta=30^{\circ}$ 付近から下流 $90 \mathrm{~cm}$ ま での外岸で $6 \mathrm{~cm}$ を越える洗掘が発生しており，その 一部は円柱群内まで進入している. 湾曲角 $\theta=60^{\circ}$ か ら下流 $90 \mathrm{~cm}$ にかけての内岸で $8 \mathrm{~cm}$ 程度の堆積が発 生している. 外岸の上流部分のみに円柱群を設置し たケース K-8では, 円柱群後方 $\theta=60^{\circ}$ までの外岸側 近傍では河床は安定している. 湾曲角 $\theta=60^{\circ}$ 付近で 堆積は $10 \mathrm{~cm}$ を越える大きなものになっている. 水路 中央部にある洗掘は外岸に進行する可能性がある. 外岸湾曲部のみに円柱群を設置したケース K-10 では, 湾曲角 $\theta=35^{\circ}$ から下流 $45 \mathrm{~cm}$ の水路中央部に $6 \mathrm{~cm}$ 超 洗掘が発生し, 円柱群内に進行している. 内岸側の 


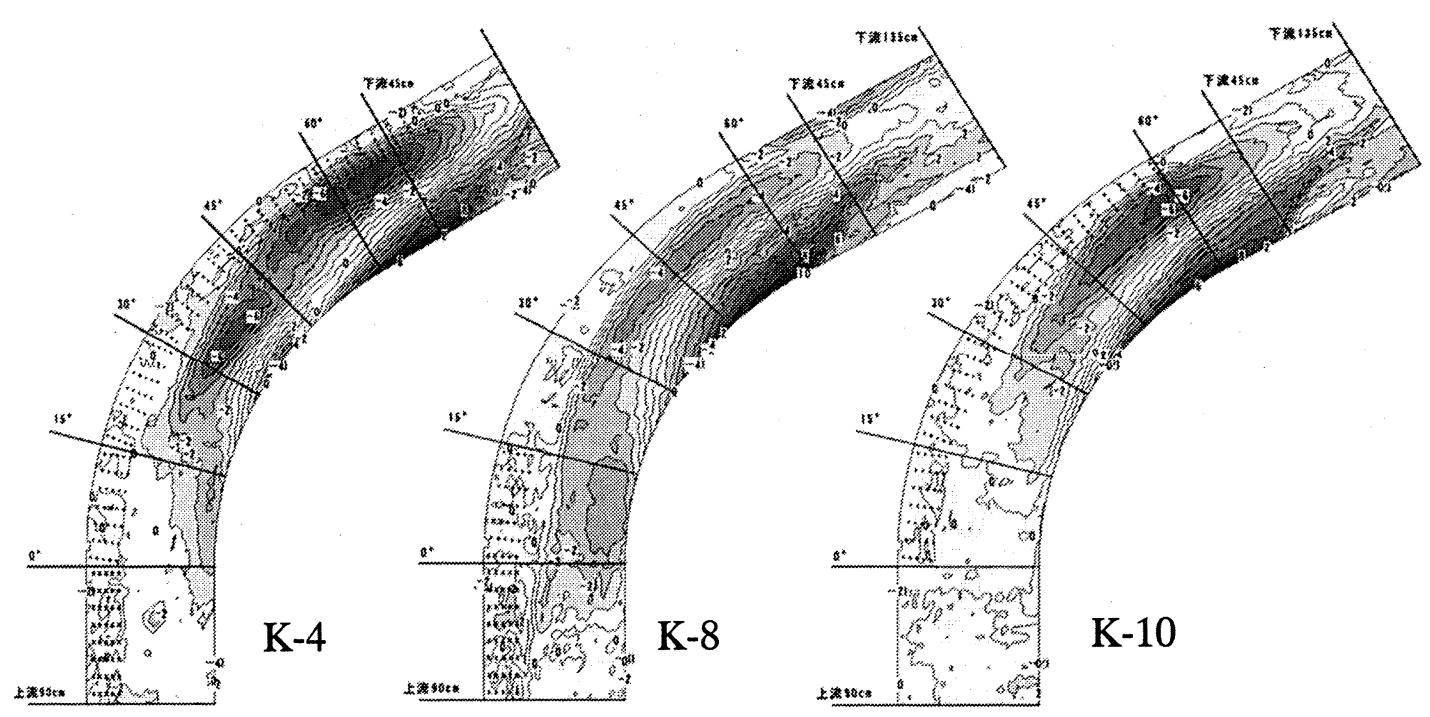

図-3 通水 5 時間後の非水没型の河床高コンター

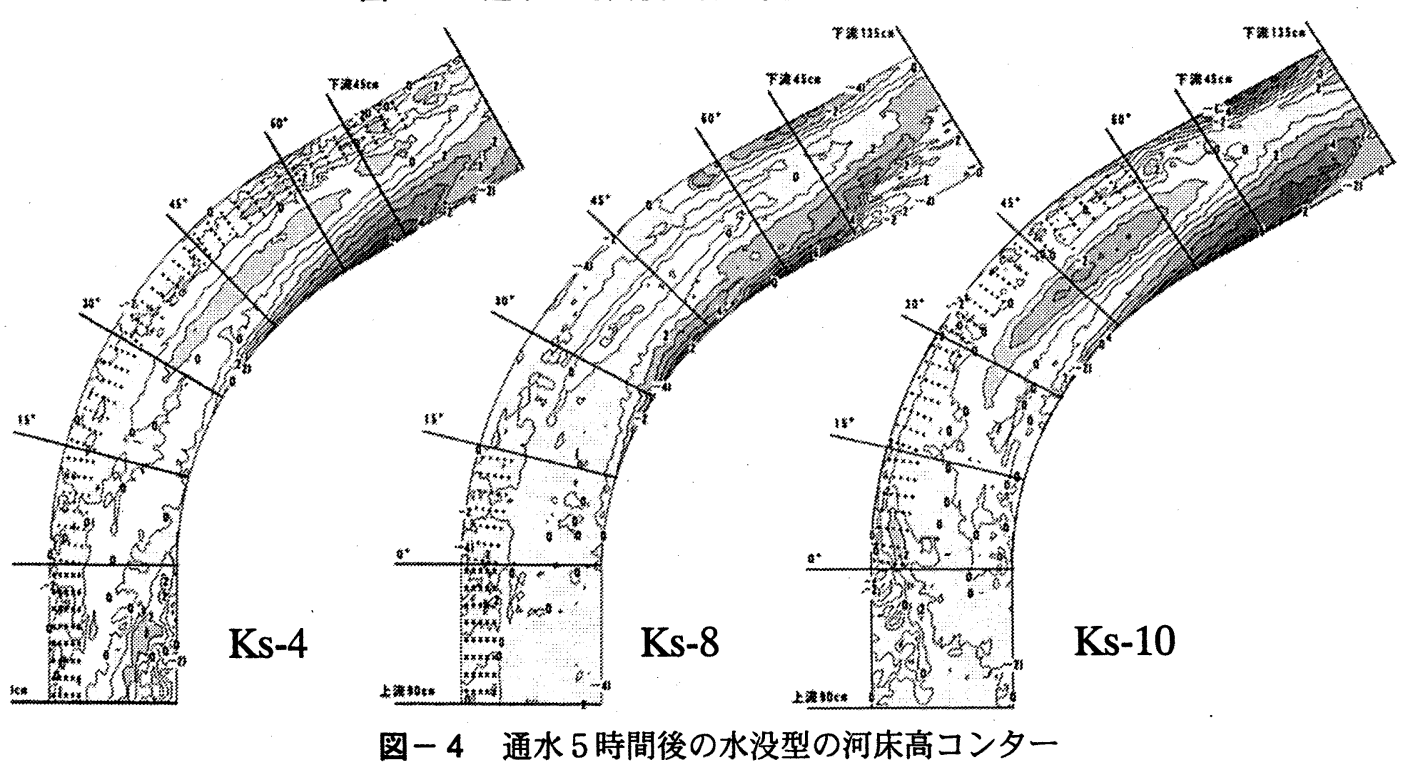

堆積は湾曲角 $\theta=45^{\circ}$ から徐々に発達していき湾曲 角 $\theta=60^{\circ}$ で最大 $8 \mathrm{~cm}$ になっている.

次に, 水没型円柱群を設置したケースについて考 察する. 外岸に円柱群を設置したケース Ks-4 では, 上流から湾曲角 $\theta=30^{\circ}$ までは大きな変化がなく安 定している. 湾曲角 $\theta=60^{\circ}$ から下流 $45 \mathrm{~cm}$ にかけて の内岸で堆積が発生している. ケース K-4 と比較す ると洗掘, 堆積の生じる場所は同じであるが, 全体 的に河床変動が抑えられ, 特に円柱群境界付近での 洗掘が抑えられている. 外岸の上流部分のみに円柱 群を設置したケース Ks-8 では湾曲角 $\theta=60^{\circ}$ 付近の 内岸で最大 $6 \mathrm{~cm}$ の堆積が発生している. ケース K-8 と比較すると洗掘, 堆積は約 3 分の 2 程度に抑えら れている. 外岸湾曲部のみに円柱群を設置したケー ス Ks-10 では外岸側の円柱群内での河床変動はほぼ $0 \mathrm{~cm}$ である. 湾曲角 $\theta=30^{\circ}$ から $\theta=60^{\circ}$ の水路中央 部付近に $2 \mathrm{~cm}$ 程度の洗掘が発生している.このケー スもまたケース K-10 と比較すると洗掘, 堆積も約 3 分の 2 程度に抑えられている. 全体的に水没型円柱 群の場合, 非水没型円柱群の場合に比べ河床変動が 抑えられる傾向にある.

\section{（2）主流速分布}

図一 5 は固定床実験における各ケースの水深平均 流速の横断分布である. 湾曲部では遠心力と釣り合 う水面勾配により，まず内岸で加速され，流下する にしたがって, 2 次流による運動量輸送も加わって 内岸の減速と外岸の加速が生じる.ケース R-5では, このような高速域の内岸から外岸への移行が認めら れた. ケース V-8 では円柱群と主流境界付近の減速 が大きくなっている. 円柱群の途切れた湾曲角 $\theta$ $=30^{\circ}$ で流速が最も遅く, そこから流下するにしたが って流速は回復している. 湾曲角 $\theta=60^{\circ}$ 以降は内岸 壁付近で流速の減少が顕著である. ケース V-10では 円柱群境界にある大きな流速勾配を示すせん断首は 流下するにしたがい円柱群内部に移っている. 下流 $45 \mathrm{~cm}$ では円柱群後方の流速は回復しているが, 外岸 壁近傍ではあまり回復せず, 内岸に 2 次流による減 速が急に現れ水路中央付近の流速が最も速くなって いる. ケース Vs-8 では円柱群が水没しないケースと 異なり全体的に水深平均流速は横断方向に均一にな っている. 円柱群の存在するところではやや減速さ れているものの, 流下するにしたがい回復している. 

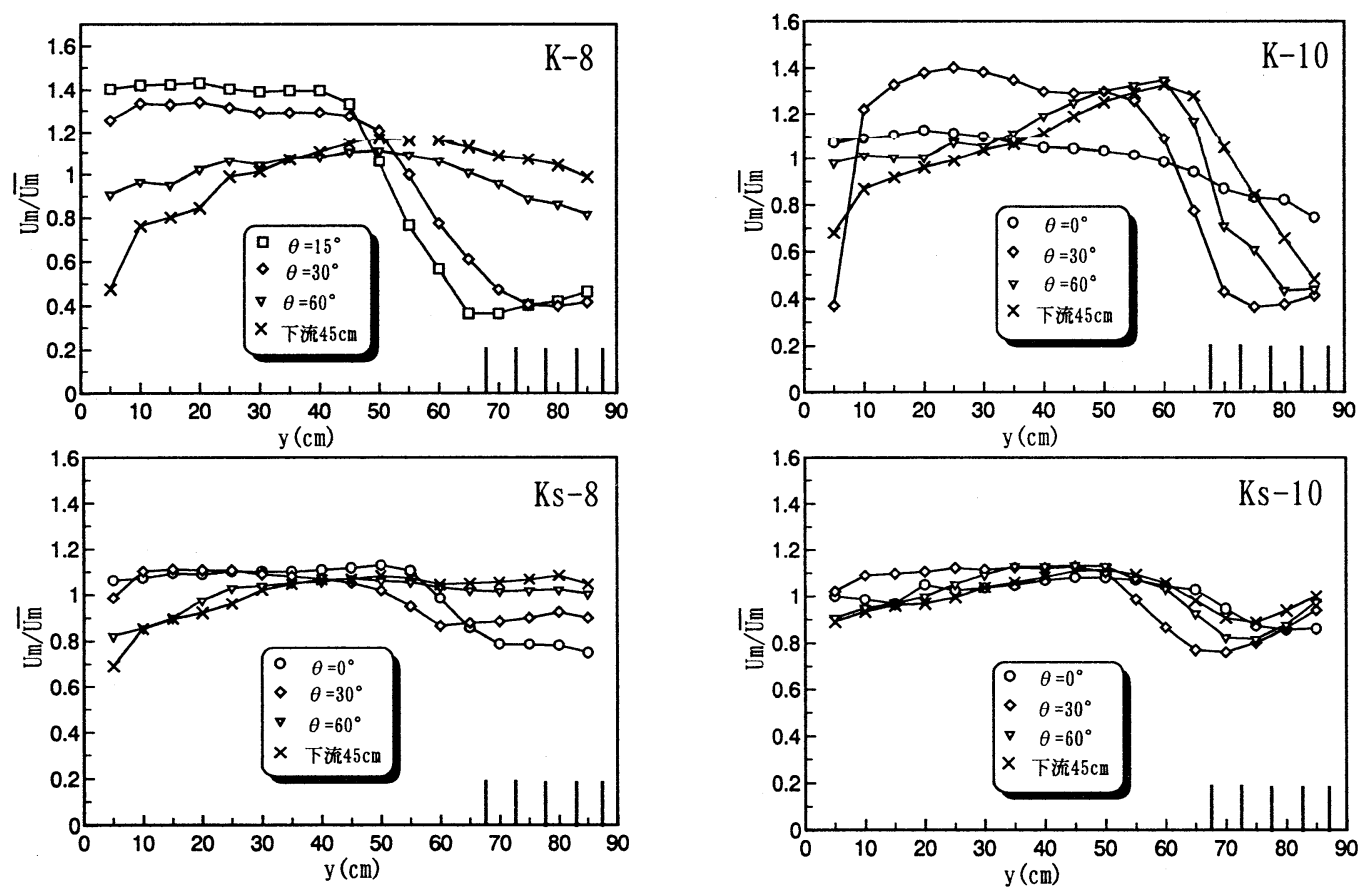

図-5 固定床における水深平均流速の横断方向分布
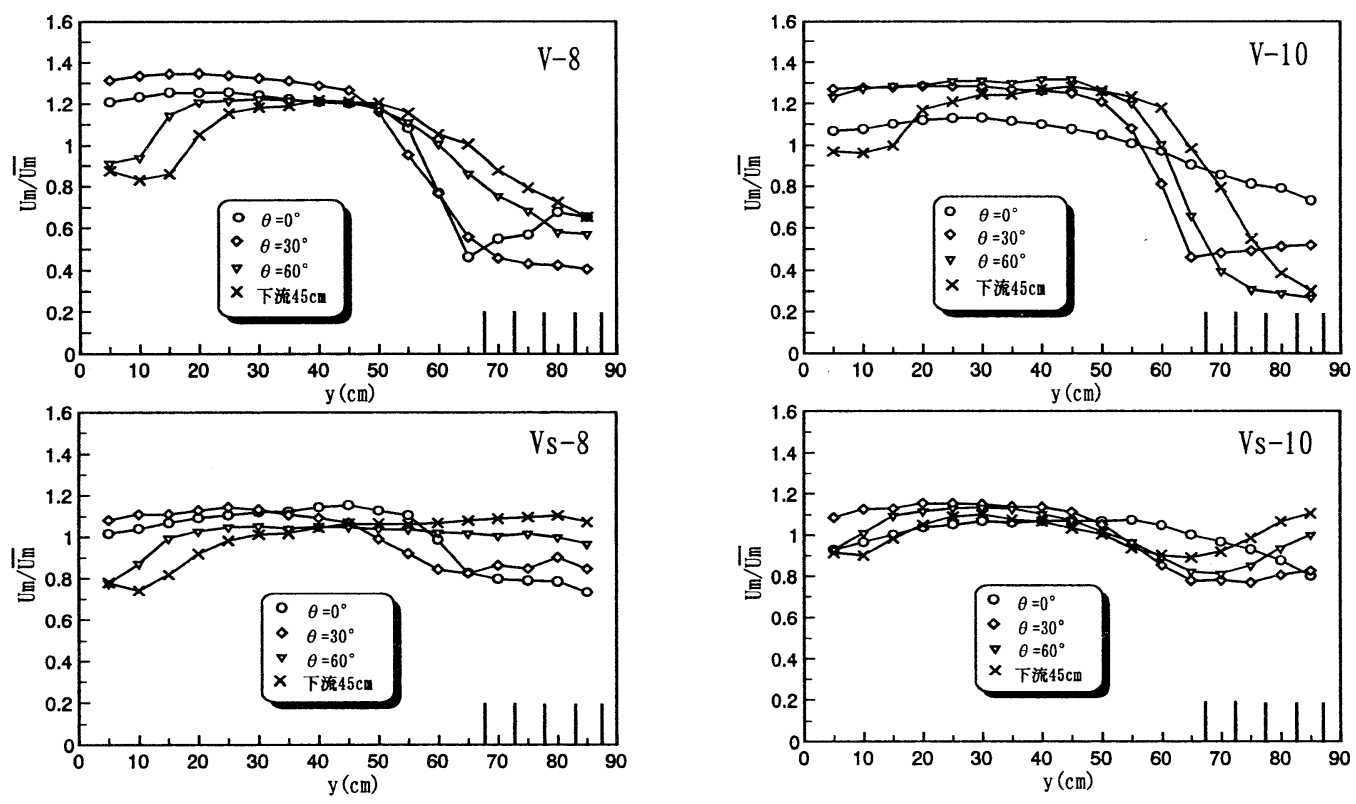

図－6 移動床における水深平均流速の横断方向分布

ケース V-8 のような円柱群による大きな減速効果や 強いせん断層を見ることはできない.ケース Vs-10 では外岸側では流下するにつれ流速は回復している が，下流 $45 \mathrm{~cm}$ では壁近傍が最も速くなっており，ケ 一ス V-10 とは異質である.このケースもまた強いせ ん断層は形成されない.

次に図ー 6 は移動床実験における各ケースの水深 平均流速の横断分布である.ケース K-8 では流下す るにしたがい内岸側の減速と外岸側の高速化が顕著 に表れ, 外岸, 内岸における流速の変化は固定床の 結果より大きなものとなった. ケース K-10では内岸 側では湾曲角 $\theta=30^{\circ}$ までは加速していき, その後 徐々に減速している. また外岸側での減速が大きく, せん断層が円柱群内部に平行移動していることがわ かる．湾曲角 $\theta=60^{\circ}$ ，下流 $45 \mathrm{~cm}$ における円柱群境
界付近が固定床よりも高速化されている. ケース Ks-8 では水路中央付近ではすべての断面において変 化が非常に小さくなっている．外岸側においてせん 断層はかなり弱い. 固定床と比較して形状, 值とも 非常によく類似している. ケース Ks-10 では内岸側 の変化は少なく水路中央付近では全く変化していな い. 固定床と同様な形をしているが外岸壁近傍での 流速の回復が遅い点が異なる.

\section{（3） 2 次流構造}

図ー 7 はケース V-10,Vs-10 の湾曲角 $\theta=60^{\circ}$ にお ける 2 次流ベクトルを示している. 2 次流構造につ いては発生・発達・減哀過程はいずれのケースにお いてもほぼ同じであった. 円柱群のない場合, 通常 の湾曲渦とこれとは逆回転の外岸渦が外岸付近に発 
生することが知られているが ${ }^{8)}$, 円柱群のない領域で 湾曲部特有の 2 次流である湾曲渦が発生する. 外岸 側に円柱群がある場合, 外岸渦が消隇する. 水没型 円柱群の場合, 円柱群を乗り越えて断面全体に及ぶ 湾曲渦が形成される.この場合外岸渦は消滅し, 渦 の中心は円柱群境界付近へ移動する. 湾曲渦は横方 向の大きさが円柱群によって制限されるが, 円柱群 がなくなると再び水路幅全体へ拡大しようとする.

また, 水没型円柱群では逆に外岸渦を消滅させ湾曲 渦を大きくしている. 二次流の強さ自体は各ケース で大きな差はなく, 形状も円柱群配置からおよそ予 測できることから, 運動量輸送及び初期砂移動に与 える二次流の効果は予測可能であるといえる.

\section{（4）底面せん断応力}

図ー8，9はそれぞれ固定床実験および移動床実 験における各ケースの底面せん断応力の流下方向分 布である. 2 次流の輸送効果はどのケースも大きな 違いがないことから, 円柱群が底面せん断応力の流 下方向分布に及ぼす影響が重要であると考えられる。 これらは円柱群の配置の違いによる水面勾配の変化, ひいては主流速の加速・減速過程の変化によって引 き起こされると考えられる. 移動床実験に用いた砂 の限界掃流力を計算すると, 固定床実験の流量にお

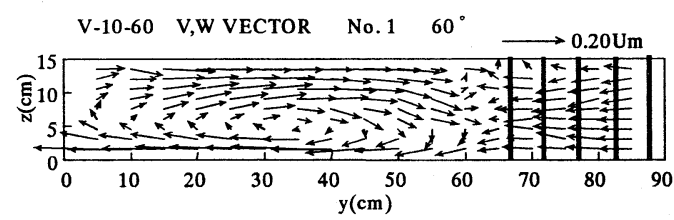

Vs-10-60 V,W VECTOR No. $160^{\circ}$

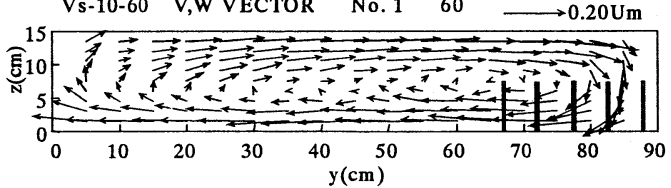

图一 7 2 次流ベクトル図
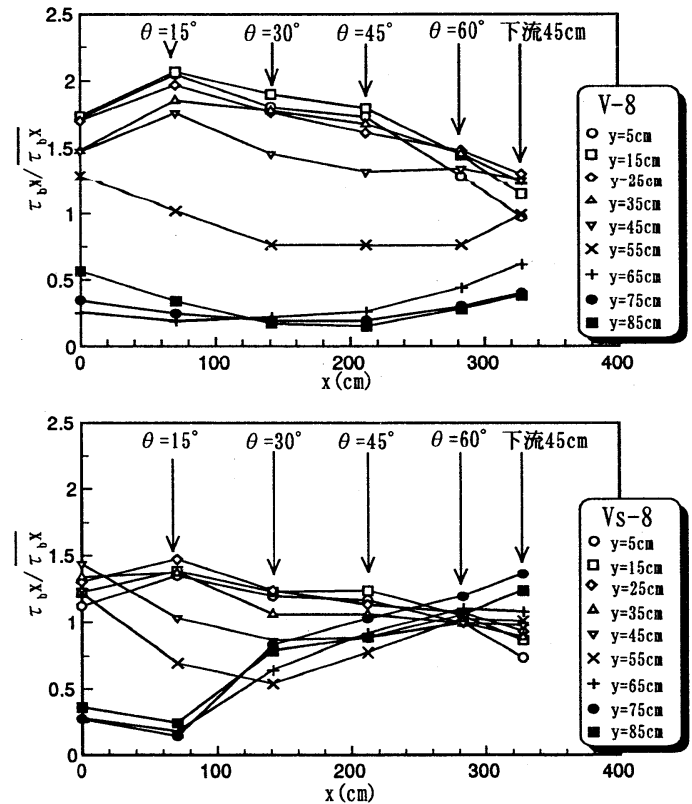

ける底面せん断応力に対して約 $\tau_{c}=1.1 \overline{\tau_{b x}}$ となった. また，移動床実験の流量においては限界掃流力は約 $\tau_{c}=1.53 \overline{\tau_{b x}}$ に相当する. ケース V-8 では内岸側で大 きな值になっているが，湾曲角 $\theta=15^{\circ}$ 以降減少し続 けている. 一方外岸側の值は小さく下流での増加も 大きくない．これに対しケース K-8 では，内岸側の せん断応力が湾曲角 $\theta=45^{\circ}$ 以降急激に減少してい る. 反対に外岸側では湾曲角 $\theta=45^{\circ}$ 以降急激に増加 しており，固定床の結果とはまったく違う形となっ ている. 固定床の分布が初期状態と考えると, 内岸 の湾曲角 $\theta=15^{\circ}$ からの減少によって堆積が始まり, これが外岸への流れの集中を引き起こしたと推測さ れる. ケース V-10 でも同様に内岸側の方が大きな值 になるが，V-8 とは異なり湾曲角 $\theta=45^{\circ}$ までは増加 していき，その後減少している，そのため内岸に若 干の洗掘が発生している. $\mathrm{y}=55 \mathrm{~cm}$, 湾曲角 $\theta=60^{\circ}$ で は限界掃流力を越えて増加しているため円柱群境界 部に大きな洗掘が生じたと考えられる。ケース K-10 では水路中央より円柱群内部にかけて, せん断応力 が湾曲角 $\theta=30^{\circ}$ 以降大きな増加を示している. 固定 床における水路中央付近のせん断応力増大による洗 掘が発達し，外岸に及んだものと考えられる．ケー ス Vs-8 では内岸側と外岸側の底面せん断応力が湾曲 角 $\theta=60^{\circ}$ で逆転している. 外岸における湾曲角 $\theta$ $=15^{\circ}$ から $\theta=30^{\circ}$ にかけて傾きが大きくなっている が，限界掃流力以下となるため河床は洗掘しないと 考えられる. ケース R-5 に類似しているが外岸側の 上流に違いがある．ケース Ks-8 では固定床と大きな 変化はなく, 内岸側と外岸側のせん断力が湾曲角 $\theta$ $=60^{\circ}$ で逆転しており, 洗掘がそれほど発達していな いことによる.内岸壁近傍でのせん断応力が流下す るにしたがい減少しており, 大きな堆積へと発達し ている. ケース Vs-10 では，ケース V-10 に比べて内 岸側のせん断応力が小さくなっている．外岸側の湾
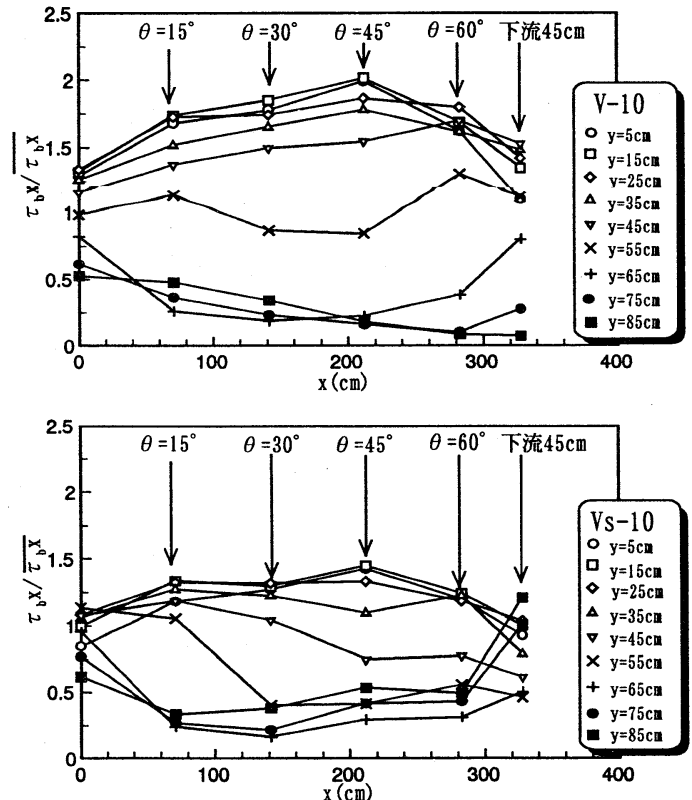

図－8 固定床における底面せん断応力の流下方向分布 

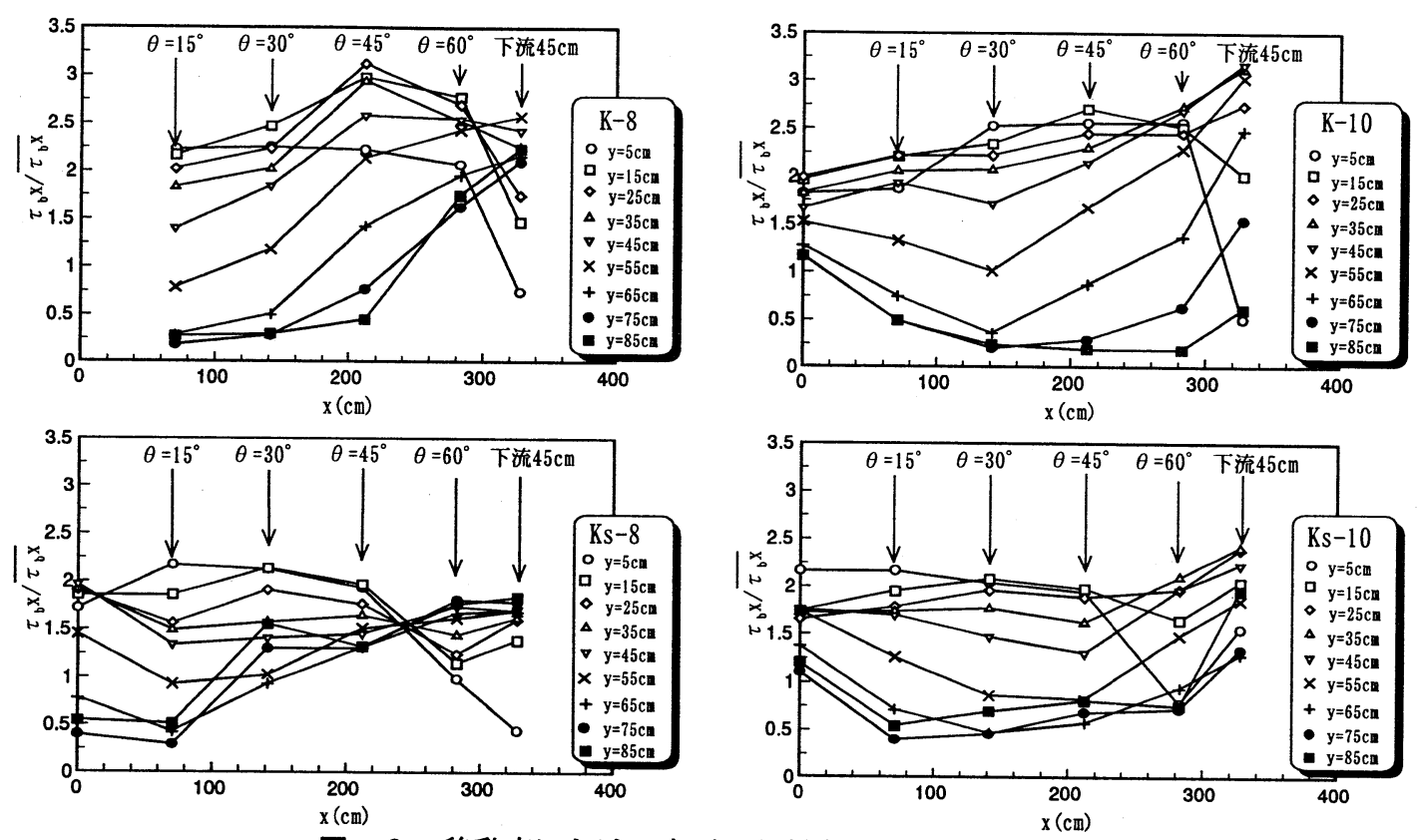

図－9 移動床における底面せん断応力の流下方向分布

曲出口から下流ではせん断応力が急増しており洗掘 する可能性がある. 円柱群が水没するケースは水没 しないケースに比べ内岸側と外岸側のせん断応力の 差が小さくなっている. ケース Ks-10 は比較的ケー ス Vs-10 に似ているが，湾曲出口以降は全体的にせ ん断応力は増加している. $\mathrm{y}=5 \mathrm{~cm}$ では湾曲角 $\theta=45^{\circ}$ で急激に減少しその後 $\theta=60^{\circ}$ で増加に転じている. ケース K-10 のように内岸側のせん断応力が大きくな ることはなく, 水没型円柱群のケースでは河床変動 が少ないことを反映して，せん断応力の傾向が固定 床の結果に良く似た形になったが，非水没型円柱群 のケースではかなり違った形になった．初期の河床 変動がせん断応力に変化を与え，変動を増幅する方 向へ進行したものと考えられる.

一般にせん断応力の流下方向の傾きが正の場合洗 掘を生じ, 負の場合堆積を生じる.これと 2 次流に よる横断力向の輸送が加わって内岸側ではせん断力 が大きいにもかかわらず堆積が生じ，外岸側では急 な増加がある場合洗掘を生じる傾向がつかめた．傾 きが大きくても洗掘や堆積が生じないのは, 円柱群 配置によってせん断応力が限界掃流力以下で増減し ているためと考えられる.

\section{4. 結論}

湾曲部に存在する円柱群の流れ構造に及ぼす影響 を, 固定床, 移動床において実験的に解明した. 固 定床における実験より, 外岸部に水没型円柱群が存 在する場合, 円柱群頂部に高速域が進入し, 断面全 体の 2 次流が形成される. 円柱群が水没する場合, 水没しない場合に比べて底面せん断応力の横断方向 変化が小さくなる. 円柱群の設置位置により底面せ ん断応力の流下方向変化過程が変化し, 限界掃流力 との関係より河床変動の特性がわかる.

次に, 移動床における実験から, 円柱群が水没す
る場合どのケースにおいても河床の変動を抑制する ことができた.この場合せん断層が鈶直方向に形成 され, 円柱群上方では流速が速く底面付近では遅い ため水深平均流速は一様化されて河床変動が抑制さ れたと考えられる，底面せん断応力は，非水没型円 柱群の場合は内岸の堆積の発達から固定床とかなり 異なる形に達したのに対し, 水没型円柱群の場合は 比較的類似した形になった. 今後はより厳密な流速 を測定することにより, 数值シミュレーションによ って河床変動軽減のメカニズムを明らかにしていく 必要がある。

\section{参考文献}

1）池田駿介: 移動床河川の湾曲部における2次流と動的横 断平衡河床について, 土木学会論文報告集, 第299号, pp.55-56, 1974.

2）石川忠晴, 全舜範: 湾曲部の2次流に関する甚礎的研究, 土木学会論文集, 第375号／II -6,pp.143-149,1986.

3）山坂昌成, 池田駿介, 酒寄建之:一様湾曲流路の流れの 3 次元解析, 土木学会論文集, 第 411 号 / II - 12 , pp.99-108, 1989

4）福岡捷二, 渡邊明英, 大橋正嘼, 姫野至彦: 樹木群の水 制的利用可能性の研究, 水工学論文集, 第 41 巻, pp.1129-1132, 1997

5) Odgaard, A. J. and Kennedy, J.F.: River-bend bank protection by submerged vanes, J. Hydr. Eng., ASCE, 109(8), pp.1161-1173, 1983

6）関根正人, 吉川秀夫, 井田泰蔵, 高松諭, 仲村学: 斜め 栈粗度による河川湾曲部の2次流抑制に関する研究, 土 木学会論文集, 第558巻／II -38, pp.61-70, 1997.

7）富永晃宏, 木村聡洋:湾曲部の流れ構造と河床形状に及 ぼす樹木群配置の影響, 水工学論文集, 第 43 巻, pp.809-814,1999.

8）富永晃宏, 長尾正志, 千葉茂樹 : 幅水梁比の小さな長 方形断面開水路の湾曲部流れ構造に関する実験的研 究，土木学会論文集，No.607/II -45，pp.19-28. 1998.

(2000.10.2 受付) 